\title{
順序依存形故障論理を用いた安全度水準決定の定式化*
}

\author{
吉 村 達*1，佐 藤 吉 信*1
}

\section{Formulation for Determining SIL using Sequential Failure Logic}

\author{
Itaru YOSHIMURA*2 and Yoshinobu SATO \\ ${ }^{* 2}$ Graduate School of Marine Science and Technology, Tokyo University of Marine Science and Technology, \\ 2-1-6 Etyujima, Koto-ku, Tokyo, 135-8533 Japan
}

\begin{abstract}
Recently computer systems have been widely applied to safety-related systems for achievement of safety functions. This general trend forced IEC to compile IEC 61508 as a standard related to functional safety of electrical/electronic/programmable electronic safety-related systems, i.e., E/E/ PE SRS (SRS). Currently JIS includes the translated standard of IEC 61508, JIS C 0508 . In accordance with the standard, an SRS is specified with its safety function (s) and safety integrity level (s) (SIL) and the SILs to be allocated to the SRS are specified with four levels of safety integrity. The standard requires assessing the risk reduction achieved by SRS using appropriate probabilistic techniques for allocation of SILs to SRS. However, the relationships among SILs, operation modes and hazardous event frequencies are not always cleared up yet. This paper presents a new model using two Sequential Failure Logics in order to describe causation of hazardous events in the overall system composed of equipment under control (EUC), EUC control system (BCS) and SRS. The SRS is assumed to implement a safety function in a dynamic demand state and assumed to have no automatic self-diagnosis functions. Then, the relationship among a dangerous undetected failure of SRS, demands for actuation of SRS and hazardous events brought about in the overall system is formulated based on the model. Moreover, new demand modes of operation and estimations of Hazardous Event Frequencies are proposed for allocation of SILs to SRS.
\end{abstract}

Key Words: Functional Safety, IEC 61508, Safety Integrity Level, Hazardous Event Frequencies, Sequential Failure Logic, Dynamic Demand State

1. は じめに

近年, 安全に関連した機能を担うためにコンピュー 夕を用いたシステムが使用されてきており,これらの 機能安全に関する国際規格 IEC 61508 及び JIS C 0508 が発効され(1)(2), 種々の方面で適用されつつある(3)(4). 規格では, 電気·電子・ブログラマブル電子安全関連 系（以下, SRS）による機能安全を全安全ライフサイ クルと安全度水準（以下, SIL）との二つの基本的な 方法論で確保している. 特に後者は, SRSによって㬰 行される安全機能遂行失敗確率の目標水準を定める指 標であり，SILについては二種類の運用モードに対し， 各々四つのレベルが設定されている.

また, SRS への SIL の割り当て過程においては, 確 率論的手法を用いてリスク軽減目標, 寸なわち単位時 間当たりの危険事象発生回数の統計的期待值（以下,

\footnotetext{
$*$ 原稿受付 2003 年 6 月 26 日.

*1 正員, 東京海洋大学大学院海洋科学技術研究科( 135-8533 東京都江東区越中島 2-1-6).

E-mail : yoshi@e.kaiyodai.ac.jp
}

単に危険事象頻度）の低減目標の達成を評価すること が推奖されている(1)(2). しかし，このために必要とな る SIL, 作動要求頻度および危険事象頻度の関係につ いて, 完全には明らかにされていない。

このような問題を解決すべく，加藤らは SRS に自 己診断機能がなくブルーフテストによってのみ修復さ れ，かつ作動要求が定常状態の場合に対して，順序依 存形故障論理を用いた危険事象モデルを定量化して危 険事象頻度を計算するためのアルゴリズムを提案した (5) (6). 順序依存形故障論理とは, 出力事象の生起が入 力事象の発生順序にも依存する最小カッ卜優先 AND 構造を用いて入出力の関係をモデル化する手法であり (7), 人間-ロボットシステム等に応用されている(7)(8). また，川原らはSRS のフォールトに対して自己診 断があり，その検出により修理が行われる場合の SRS の危険側故障, 定常作動要求状態及び危険事象の関係 を,順序依存形故障論理と状態遷移図とによってモデ ル化及び定式化している( ${ }^{(1)}$. $。$ その結果, 両モデルか 
ら得られる危険事象頻度推定式は一致することが示さ れている(9)(10).

本研究では，自己診断がないSRS について，非定 常作動要求状態における危険事象過程を加藤らと同様 に順序依存形故障論理を用いてモデル化・定式化し， 平均危険事象頻度推定式を導出する. 用語法は原則と

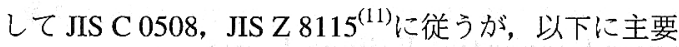
なものを記す。

危険状態 人が潜在危険に曝露されている状況.

危険事象 危険状態によって危害が生じる事象.

リスク 危険事象の蓋然性と危害の過酷さの組合せ。 （本研究では危害の過酷さは一定として，危険事 象の圔然性のみを扱う)

作動要求状態 特定の安全機能の実行がSRS に要求 される全体システムの状態 (図 1 参照).

作動要求 作動要求状態の発生.

完了 作動要求状態の終結.

フォールトある要求された機能が遂行不可能なア イテムの状態.フォールトの形態は，例えば，遂 行不能な機能の性質によって, 安全側のフォール ト，危険側のフォールトのように分類することが できる。

危険側フォールト SRS の安全機能が閭失している 状態. 全フォールトの部分集合.

DUフォールト 自己診断のない危険側フォールト. プルーフテストまたは危険事象によってのみ発見 される。

故障 ある機能エニットの要求される機能遂行能力 の終結 (事象).SRS は故障の後,フォールトと なる。

危険側故障 危険側フォールトをもたらす故障（以 下，単に故障という)

プルーフテスト SRS のフォールトを見つけるため に実施される定期テストと保全。必要に応じて， システムを“新品”又は実際上これに近い状態に 修復するために, これを行う. (以下, PTという)

PT 間隔 PT 終了から次の PT 開始までの時間間隔.

SRS EUC を安全な状態に移行させるため, 又は EUCの安全な状態を維持するために必要な安全 機能を行い, かつ, 要求される安全機能に対して 必要な安全度水準を達成するシステム。

以下に記号を定義する：

$Q_{d}(t)$ 全体システムが時刻 $t$ で作動要求状態にある 確率
Overall System

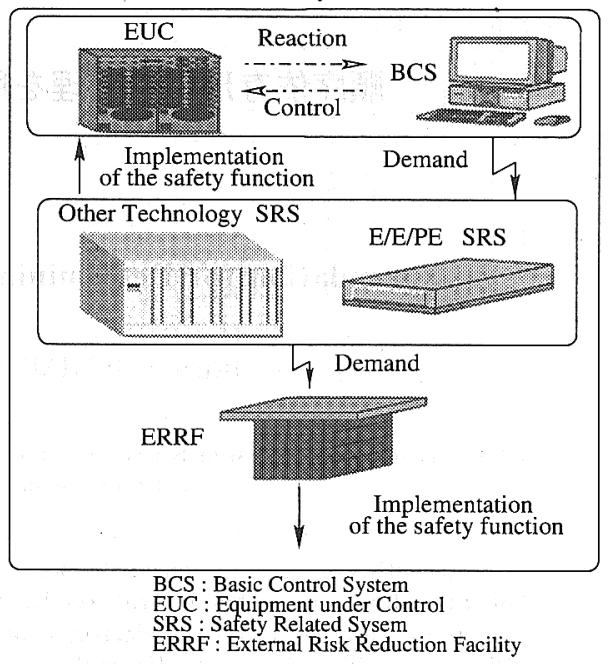

Fig. 1 Overall system and safety-related systems

$\lambda_{d}[1 / h]$ 時刻 $t$ において作動要求状態でない条件下 で，時刻 $t$ における単位時間当たりの作動要求の 発生確率（作動要求率)

$\mu_{d}[1 / h]$ 時刻 $t$ において作動要求状態の条件下で, 時刻 $t$ における単位時間当たりの作動要求の完了 確率 (完了率)

$\lambda_{s}[1 / h]$ SRS 0 危険側故障率（以下，単に故障率と いう.)

$T[h]$ 定められた PT 間隔時間

$\omega_{i}(t)[1 / h]$ 時刻 $t$ での論理 (i)（ただし， $\left.i=1,2\right) に$ よる危険事象頻度 (次章参照)

$\omega(t)[1 / h]$ 時刻 $t$ での論理（1）及び（2）による危 険事象頻度の合計

$\omega^{*}[1 / h] \omega(t)$ をPT 間隔時間 $T$ にわたって平均した $\mathrm{PT}$ 間隔平均危険事象頻度

$t, u, T[h]$ 時間のパラメータ

\section{2. 全体システムの構成と順序依存形危険事象論理}

規格では，図 1 に示すように，全体システムの構成 はEUC, EUC制御系 (以下, BCS), SRS, 他技術安 全関連系及び外的りスク軽減施設（以下，ERRF）で モデル化されている. BCS は危険事象またはその他の 望ましくない事象が発生しないように EUC を制御し, SRS，他技術安全関連系及び ERRF は BCS が制御に 失敗した時などに生じる危害を防止する冗長サブシス テムである。これらのサブシステムが機能できない状 態で作動要求が発生すると，事故など危険事象が発生 


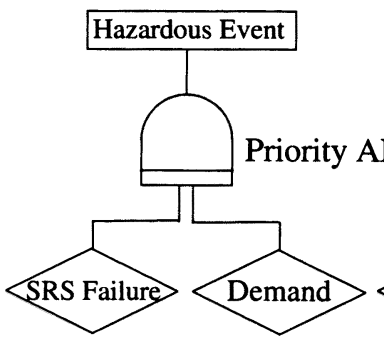

(a) Logic (1)

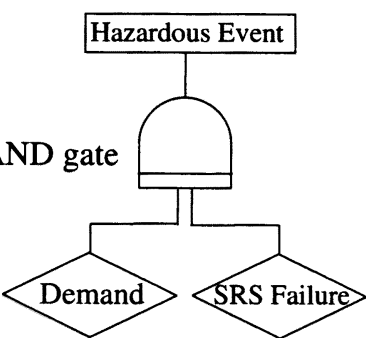

(b) Logic (2)

Fig. 2 Sequential failure logics

する ${ }^{(4)(12)}$. 加藤らや川原らが想定した全体システム は, このようなシステムを簡略化した, 一基の EUC, BCS およびSRS で構成され，このうち SRS は単一の 安全機能を遂行するものであった ${ }^{(5)(9)(10)}$.また, PT やSRS の保全時にも EUC を停止せず, 従って作動要 求は定常状態と仮定している. 本研究では, 同様の構 成の全体システムを対象としてモデル化及び定式化す るが, PT 時には EUC を停止させるので, 作動要求 が非定常状態となる点が従来の研究と本質的に異なる (5) (6) (9) (10)

このように簡易化した全体システムにおける危険事 象論理は, 優先 AND ゲートを用いて図 2 のように表 現される ${ }^{(5)(9)}$. 本図から以下の二つの危険事象論理が 成り立つ.すなわち,

1.「DU フォールト・作動要求」論理 : SRS の DU フォールト時に, 作動要求が生じて危険事象が生 起する. (以下, この危険事象論理を論理（1）と いう.)

2.「作動要求状態・故障」論理 : 作動要求状態時に, SRS に故障が生じて危険事象が生起する. (以下, この危険事象論理を論理（2）という.）

\section{3. 危険事象頻度の定专化}

本章では，前述した論理（1）及び（2）を用いて危 険事象頻度推定式を導出する. まず前提条件は以下の 通りである。

1. 作動要求と故障は, 相互に統計的に独立である.

2. 作動要求の発生と完了は, 作動要求率 $\lambda_{d}$ 及び完 了率 $\mu_{d}$ を持つ指数分布でモデル化できる.

3. SRS の故障は故障率 $\lambda_{s}$ をもつ指数分布でモデル 化され, 当該危険側フォールトはPT または危険 事象により検知・修復されるまで継続する.すな わち, 故障はDUフォールトのみをもたらす。ま た, $0<\lambda_{s} T \ll 1$ が常に成り立つ.

4. 危険事象が生起した場合, 全体システムは速やか

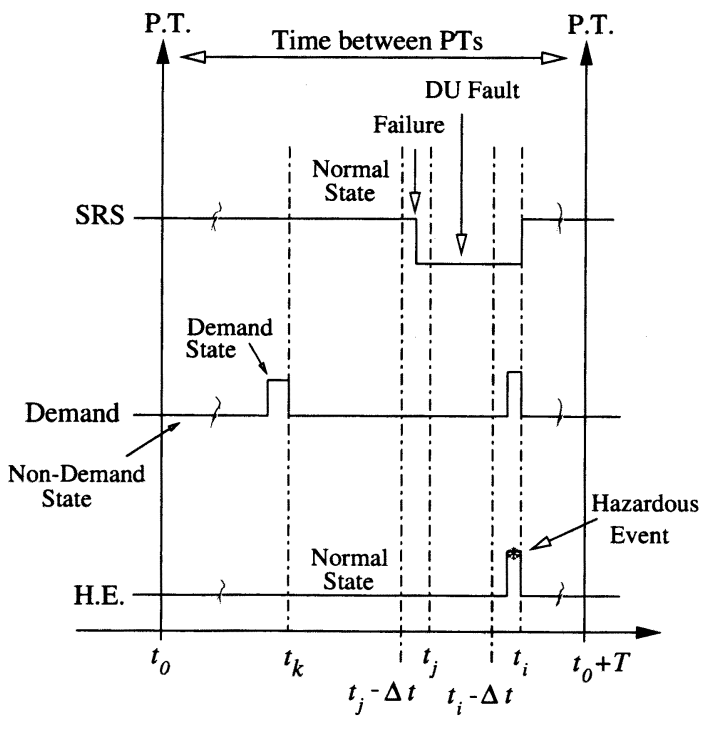

Fig. 3 Hazardous event through logic (1)

に回復する. 作動要求状態にあっても危険事象が 生起しない場合, SRS は機能していることが証明 される。

5. PT 間隔平均危険事象頻度 $\omega^{*}$ は $\omega^{*} \ll 1[1 / h]$ を 満たす。

6. PTにより, いかなる DU フォールトも検知され, SRS は新品同様に回復する.

7. PT 時に EUC を停止して保全する，すなわち, PT 時に作動要求は生じず, 従って, 危険事象も生起 しない.また，全体システムが新品同様の状態に なった時点を PT 終了時とし，このとき全体シス テムの運用を開始する.

前提条件 (3) の $\lambda_{s}$ の条件は, SRS に対する規格要 求 $\lambda_{s}<10^{-5}[1 / h]$ を根捉としている(1)(2). また, 前提 条件 (7) が従来の研究 ${ }^{(5)(6)(9)(10) ~}$ と異なる.

3.1 論理（1）における危険事象頻度推定式 SRS の故障, 作動要求 (Demand) 及び危険事象 (H.E.) の 時間推移を図 3 に示す。本研究では, 図 3 に示すよう に，あるPTが完了した時刻すなわち全体システムが 稼働し始めた時刻 $t_{0}$ から次回 PT 開始までの時刻 $t_{0}+T$ までの PT 間隔におけるリスク，すなわち危険事象頻 度の推定を行う。

図 3 中, 時刻 $t_{n}$ は, ある PT 間隔 $\left(t_{0}, t_{0}+T\right]$ を十分 に大きい数 $N$ で等分した時の, ある時刻を表してお り $t_{n}=t_{0}+n \Delta t(n=1,2,3 \cdots, N), \Delta t=T / N$ である. ま た, $t_{0}<t_{k}<t_{j}<t_{i}<t_{0}+T$ が常に成り立つ.

図 3 より,まず微小時間 $\left(t_{j}-\Delta t, t_{j}\right]$ で SRS の故障が 
発生してDUフォールトとなり, 次に同じく微小時間 $\left(t_{i}-\Delta t, t_{i}\right]$ で作動要求が発生して, 危険事象が全体シ ステムに生起する. その後, 前提条件（4）により全 体システムは速やかに回復する. また, 前提条件 (2) 及び（3）より SRS の故障及び作動要求は指数分布を 仮定しているので, 微小時間 $\left(t_{i}-\Delta t, t_{i}\right]$ でそれらが 2 回以上発生する確率は $o(\Delta t)$ である ${ }^{(13)}$. 従って, 危険 事象も当該微小時間で 2 回以上発生する確率は $o(\Delta t)$ となる. 即ち,

$\operatorname{Pr}\left\{\left(t_{i}-\Delta t, t_{i}\right]\right.$ で危険事象が発生 $\}=\omega_{1}\left(t_{i}\right) \Delta t+o(\Delta t)(1)$ と書けるので,

$$
\omega_{1}\left(t_{i}\right) \Delta t=\sum_{j=1}^{i} \operatorname{Pr}\left\{\left(t_{j}-\Delta t, t_{j}\right]\right. \text { で発生した SRS の }
$$

故障が $t_{i}$ までは修復されておらず, かつ

$\left[t_{j}-\Delta t, t_{i}-\Delta t\right]$ で作動要求状態でない条件下で

$\left(t_{i}-\Delta t, t_{i}\right]$ において作動要求が発生する $\}$.

ここで上記の記述を以下のような記号に置き換える. すなわち

$U_{0}: t_{j}-\Delta t$ で SRS が DU フォールトでない, $U_{1}:\left(t_{j}-\Delta t, t_{j}\right]$ で SRS に故障が発生する, $U_{2}: \mathrm{SRS}$ のDU フォールトが $t_{i}$ まで修復されない, $U_{3}:\left[t_{j}-\Delta t, t_{i}-\Delta t\right]$ で作動要求状態にない, $U_{4}$ : 時刻 $t_{j}-\Delta t$ 以降の最初の作動要求が $\left(t_{i}-\Delta t, t_{i}\right]$

で生ずる.

すると, 前提条件 (1) より, $U_{0}$ と $U_{3}, U_{0}$ と $U_{4}, U_{1}$ と $U_{3}, U_{1}$ と $U_{4}, U_{2}$ と $U_{3}$ 及び $U_{2}$ と $U_{4}$ とはそれぞ れ相互に独立, さらに前提条件 (3) より $\operatorname{Pr}\left\{U_{2} \mid U_{0} \cap\right.$ $\left.U_{1} \cap U_{3} \cap U_{4}\right\}=1$ であるから,

$$
\begin{aligned}
\omega_{1}\left(t_{i}\right) \Delta t & =\sum_{j=1}^{i} \operatorname{Pr}\left\{U_{0} \cap U_{1} \cap U_{2} \cap U_{3} \cap U_{4}\right\} \\
& =\sum_{j=1}^{i} \operatorname{Pr}\left\{U_{0}\right\} \operatorname{Pr}\left\{U_{1} \mid U_{0}\right\} \operatorname{Pr}\left\{U_{3}\right\} \operatorname{Pr}\left\{U_{4} \mid U_{3}\right\} .
\end{aligned}
$$

$\operatorname{Pr}\left\{U_{0}\right\}$ は時刻 $t_{j}-\Delta t$ 以前に発生した最後の作動要 求が時刻 $t_{k}$ で完了し, SRS が時刻 $t_{k}$ から時刻 $t_{j}-\Delta t$ まで故障しない確率であるから，前提条件（3）より

$$
\operatorname{Pr}\left\{U_{0}\right\}=e^{-\lambda_{s}\left(t_{j}-\Delta t-t_{k}\right)}=e^{-\lambda_{s}(j-k-1) \Delta t} \simeq 1 .
$$

ここで,

$$
\operatorname{Pr}\left\{U_{1} \mid U_{0}\right\}=\lambda_{s} \Delta t
$$

次に $U_{3}$ を以下のように置き換える. すなわち,

$$
\operatorname{Pr}\left\{U_{3}\right\} \equiv \operatorname{Pr}\left\{U_{3}^{\prime} \cap U_{3}^{\prime \prime}\right\}=\operatorname{Pr}\left\{U_{3}^{\prime}\right\} \operatorname{Pr}\left\{U_{3}^{\prime \prime} \mid U_{3}^{\prime}\right\} .
$$

ただし，

$$
\begin{aligned}
& U_{3}^{\prime}: t_{j}-\Delta t \text { で作動要求状態でない, } \\
& U_{3}^{\prime \prime}: t_{i}-\Delta t \text { まで作動要求が生じない. }
\end{aligned}
$$

ここで記号の定義より $\operatorname{Pr}\left\{U_{3}^{\prime}\right\}=1-Q_{d}\left(t_{j}-\Delta t\right)$, $\operatorname{Pr}\left\{U_{3}^{\prime \prime} \mid U_{3}^{\prime}\right\}$ は時刻 $t_{k}$ から時刻 $t_{j}-\Delta t$ まで作動要求が 発生しなかった条件下で, 引き続き時刻 $t_{i}-\Delta t$ まで作 動要求が発生しない確率であるから

$$
\begin{aligned}
\operatorname{Pr}\left\{U_{3}\right\} & =\operatorname{Pr}\left\{U_{3}^{\prime}\right\} \operatorname{Pr}\left\{U_{3}^{\prime \prime} \mid U_{3}^{\prime}\right\} \\
& =\left(1-Q_{d}\left(t_{j}-\Delta t\right)\right) \frac{e^{-\lambda_{d}\left(t_{i}-\Delta t-t_{k}\right)}}{e^{-\lambda_{d}\left(t_{j}-\Delta t-t_{k}\right)}} \\
& =\left(1-Q_{d}\left(t_{j}-\Delta t\right)\right) e^{-\lambda_{d}\left(t_{i}-t_{j}\right)} .
\end{aligned}
$$

また，

$$
\operatorname{Pr}\left\{U_{4} \mid U_{3}\right\}=\lambda_{d} \Delta t .
$$

式（3）から（7）より,

$$
\begin{aligned}
& \omega_{1}\left(t_{i}\right) \Delta t=\sum_{j=1}^{i} \lambda_{s} \Delta t\left(1-Q_{d}\left(t_{j}-\Delta t\right)\right) e^{-\lambda_{d}\left(t_{i}-t_{j}\right)} \lambda_{d} \Delta t . \\
& t_{i}=t, t_{j}=u \text { とおき, さらに } N \rightarrow \infty \text { とすると } \\
& \omega_{1}(t)=\int_{t_{0}}^{t} \lambda_{s} \lambda_{d}\left(1-Q_{d}(u)\right) e^{-\lambda_{d}(t-u)} d u .
\end{aligned}
$$

3.2 論理（2）における危険事象頻度推定式 SRS の故障, 作動要求 (Demand) 及び危険事象 (H.E.) の時 間推移を図 4 に示す. 図 3 と同様に $t_{n}=t_{0}+n \Delta t(n=$ $1,2,3 \cdots, N), \Delta t=T / N$ である. また, $t_{0}<t_{j}<t_{i}<$ $t_{0}+T$ が常に成り立つ.

図 4 より,まず微小時間 $\left(t_{j}-\Delta t, t_{j}\right]$ で作動要求が 発生して作動要求状態となり, 次に同じく微小時間 $\left(t_{i}-\Delta t, t_{i}\right]$ で SRS が故障して危険事象が全体システム に生起する. その後, 前提条件 (4) により全体シス テムは速やかに回復する．前節と同様に，

$\operatorname{Pr}\left\{\left(t_{i}-\Delta t, t_{i}\right]\right.$ で危険事象が発生 $\}=\omega_{2}\left(t_{i}\right) \Delta t+o(\Delta t) .(10)$ さらに,

$\omega_{2}\left(t_{i}\right) \Delta t=\sum_{j=1}^{i} \operatorname{Pr}\left\{\left(t_{j}-\Delta t, t_{j}\right]\right.$ で発生した作動要求が $t_{i}$ まで完了せず $\left[t_{j}-\Delta t, t_{i}-\Delta t\right]$ で SRS が DU フォールトでない条件下で $\left(t_{i}-\Delta t, t_{i}\right]$ で SRS が 故障する\}. 


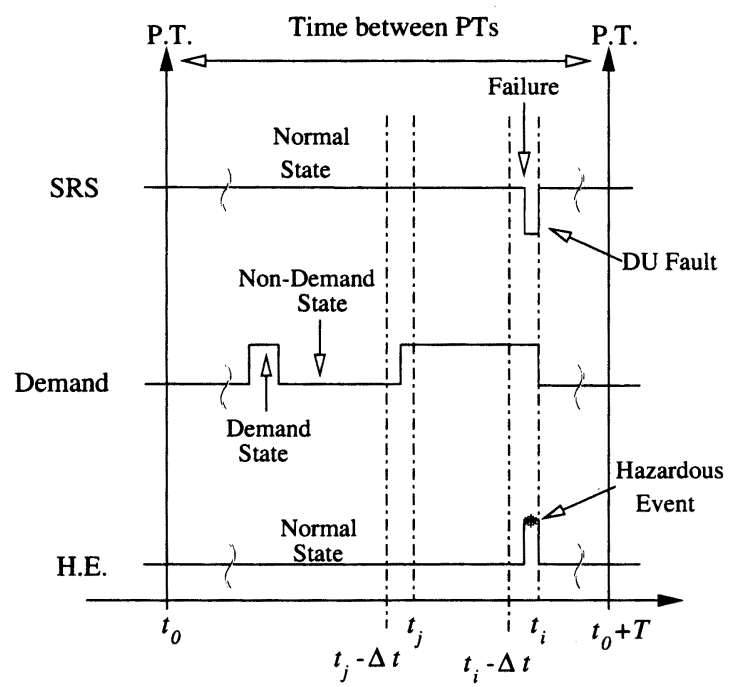

Fig. 4 Hazardous event through logic (2)

記号を，

$E_{0}$ : 時刻 $t_{j}-\Delta t$ で作動要求状態でない,

$E_{1}:\left(t_{j}-\Delta t, t_{j}\right]$ で作動要求が発生,

$E_{2}:$ 当該作動要求が $t_{i}$ までは完了しない,

$E_{3}:\left[t_{j}-\Delta t, t_{i}-\Delta t\right]$ で SRS はDU フォールトでない,

$E_{4}:\left(t_{i}-\Delta t, t_{i}\right]$ で SRS が故障する,

と定義すれば, 前提条件 (1) より, $E_{0}$ と $E_{3}, E_{0}$ と $E_{4}, E_{1}$ と $E_{3}, E_{1}$ と $E_{4}, E_{2}$ と $E_{3}$ 及び $E_{2}$ と $E_{4}$ とは それぞれ相互に独立なので, 式 (11) は,

$$
\begin{aligned}
\omega_{2}\left(t_{i}\right) \Delta t= & \sum_{j=1}^{i} \operatorname{Pr}\left\{E_{0} \cap E_{1} \cap E_{2} \cap E_{3} \cap E_{4}\right\} \\
= & \sum_{j=1}^{i} \operatorname{Pr}\left\{E_{0}\right\} \operatorname{Pr}\left\{E_{1} \mid E_{0}\right\} \operatorname{Pr}\left\{E_{2} \mid E_{0} \cap E_{1}\right\} \\
& \times \operatorname{Pr}\left\{E_{3}\right\} \operatorname{Pr}\left\{E_{4} \mid E_{3}\right\} .
\end{aligned}
$$

ここで,

$$
\begin{aligned}
& \operatorname{Pr}\left\{E_{0}\right\}=1-Q_{d}\left(t_{j}-\Delta t\right), \\
& \operatorname{Pr}\left\{E_{1} \mid E_{0}\right\}=\lambda_{d} \Delta t, \\
& \operatorname{Pr}\left\{E_{2} \mid E_{0} \cap E_{1}\right\}=e^{-\mu_{d}\left(t_{i}-t_{j}\right)} .
\end{aligned}
$$

次に $E_{3}$ である確率をもとめる. まず $E_{3}$ を以下のよ うに置き換える.すなわち,

$$
\operatorname{Pr}\left\{E_{3}\right\} \equiv \operatorname{Pr}\left\{E_{3}^{\prime} \cap E_{3}^{\prime \prime}\right\}=\operatorname{Pr}\left\{E_{3}^{\prime}\right\} \operatorname{Pr}\left\{E_{3}^{\prime \prime} \mid E_{3}^{\prime}\right\} .
$$
ただし，

$E_{3}^{\prime}:\left(t_{j}-\Delta t, t_{j}\right]$ で SRS が DU フォールトでない, $E_{3}^{\prime \prime}$ : 時刻 $t_{i}-\Delta t$ まで故障しない.
もし時刻 $t_{j}-\Delta t$ で SRS がDUフォールトの場合, こ の時点で危険事象が生起してしまい,これは論理（1） に該当する. また, 故障と作動要求が微小時間内に両 方発生する確率は $o(\Delta t)$ となるのでこれを無視し, 本 論理においては当該時刻において SRS がDU フォール トでない場合のみを考慮する. すると, $\operatorname{Pr}\left\{E_{3}^{\prime}\right\}=1$, さ らに前提条件（4）より作動要求が発生した $\left(t_{j}-\Delta t, t_{j}\right]$ において危険事象が生起しなかったことで SRS の正常 状態が確認できるので $\operatorname{Pr}\left\{E_{3}^{\prime \prime} \mid E_{3}^{\prime}\right\}=e^{-\lambda_{s}\left(t_{i}-\Delta t-\left(t_{j}-\Delta t\right)\right)}$. 従って, 前提条件（3）より,

$$
\begin{aligned}
\operatorname{Pr}\left\{E_{3}\right\} & =\operatorname{Pr}\left\{E_{3}^{\prime}\right\} \operatorname{Pr}\left\{E_{3}^{\prime \prime} \mid E_{3}^{\prime}\right\}=e^{-\lambda_{s}\left(t_{i}-t_{j}\right)} \\
& =e^{-\lambda_{s}(i-j) \Delta t} \simeq 1 .
\end{aligned}
$$

また，

$$
\operatorname{Pr}\left\{E_{4} \mid E_{3}\right\}=\lambda_{s} \Delta t
$$

式（12）から（17）より .

$$
\begin{aligned}
& \omega_{2}\left(t_{i}\right) \Delta t=\sum_{j=1}^{i}\left(1-Q_{d}\left(t_{j}-\Delta t\right)\right) \lambda_{d} \Delta t e^{-\mu_{d}\left(t_{i}-t_{j}\right)} \lambda_{s} \Delta t . \\
& t_{i}=t, t_{j}=u \text { とおき, さらに } N \rightarrow \infty \text { とすると } \\
& \omega_{2}(t)=\int_{t_{0}}^{t} \lambda_{s} \lambda_{d}\left(1-Q_{d}(u)\right) e^{-\mu_{d}(t-u)} d u .
\end{aligned}
$$

3.3 PT 間隔平均危険事象頻度論理（1）と（2） は相互に排反であるから, 式 (9) 及び (19) から $\omega(t)$ は,

$$
\begin{aligned}
& \omega(t)=\omega_{1}(t)+\omega_{2}(t) \\
= & \int_{t_{0}}^{t} \lambda_{s} \lambda_{d}\left(1-Q_{d}(u)\right)\left(e^{-\lambda_{d}(t-u)}+e^{-\mu_{d}(t-u)}\right) d u . \text { (20) }
\end{aligned}
$$

任意の PT 間隔 $\left(t_{0}, t_{0}+T\right]$ における $\omega^{*}$ は,

$$
\begin{gathered}
\omega^{*}=\frac{\int_{t_{0}}^{t_{0}+T} \omega(t) d t}{T}=\frac{\lambda_{s} \lambda_{d}}{T} \\
\times \int_{t_{0}}^{t_{0}+T} \int_{t_{0}}^{t}\left(1-Q_{d}(u)\right)\left(e^{-\lambda_{d}(t-u)}+e^{-\mu_{d}(t-u)}\right) d u d t .(
\end{gathered}
$$

前提条件（6）より, 各 PT 間隔における危険事象発 生過程は同様になるので $t_{0}=0$ としても一般性を失わ ない. 時刻 $u$ において作動要求状態にある確率 $Q_{d}(u)$ は ${ }^{(14)}$,

$$
Q_{d}(u)=\frac{\lambda_{d}}{\lambda_{d}+\mu_{d}}\left(1-e^{-\left(\lambda_{d}+\mu_{d}\right) u}\right) .
$$

式（21）及び（22）より,

$$
\begin{aligned}
& \omega^{*}=\frac{\lambda_{s} \lambda_{d}}{T} \int_{0}^{T} \int_{0}^{t}\left(1-Q_{d}(u)\right)\left(e^{-\lambda_{d}(t-u)}+e^{-\mu_{d}(t-u)}\right) d u d t \\
= & \lambda_{s}\left(1-\frac{\mu_{d}}{\lambda_{d}\left(\lambda_{d}+\mu_{d}\right) T}-\frac{\lambda_{d}-\mu_{d}}{\lambda_{d} \mu_{d} T} e^{-\lambda_{d} T}\right. \\
& \left.+\frac{\lambda_{d}}{\mu_{d}\left(\lambda_{d}+\mu_{d}\right) T} e^{-\left(\lambda_{d}+\mu_{d}\right) T}\right) .
\end{aligned}
$$


Table 1 New modes of operation for allocation of SILs for dynamic demand-state SRSs without selfdiagnosis

\begin{tabular}{|c|c|}
\hline 作動要求モード & $\begin{array}{l}\text { PT 間隔平均 } \\
\text { 危険事象頻度 }\end{array}[1 / h]$ \\
\hline $\begin{array}{c}\text { 低頻度-短継続 } \\
\left(\lambda_{d} \ll 1 / T \text { and } \mu_{d} \gg 1 / T\right)\end{array}$ & $0.5 \lambda_{s} \lambda_{d} T$ \\
\hline $\begin{array}{c}\text { 低頻度-中継続 } \\
\left(\lambda_{d} \ll 1 / T \text { and } \mu_{d} \simeq 1 / T\right)\end{array}$ & $0.87 \lambda_{s} \lambda_{d} T$ \\
\hline $\begin{array}{c}\text { 低頻度-長継続 } \\
\left(\lambda_{d} \ll 1 / T \text { and } \mu_{d} \ll 1 / T\right)\end{array}$ & $\lambda_{s} \lambda_{d} T$ \\
\hline $\begin{array}{c}\text { 中頻度-短継続 } \\
\left(\lambda_{d} \simeq 1 / T \text { and } \mu_{d} \gg 1 / T\right)\end{array}$ & $0.37 \lambda_{s}$ \\
\hline $\begin{array}{c}\text { 中頻度-中継続 } \\
\left(\lambda_{d} \simeq \mu_{d} \simeq 1 / T\right)\end{array}$ & $0.57 \lambda_{s}$ \\
\hline $\begin{array}{c}\text { 中頻度-長継続 } \\
\left(\lambda_{d} \simeq 1 / T \text { and } \mu_{d} \ll 1 / T\right) \\
\text { 高頻度-短継続 } \\
\left(\lambda_{d} \gg 1 / T \text { and } \mu_{d} \gg 1 / T\right) \\
\text { 高頻度-中継続 } \\
\left(\lambda_{d} \gg 1 / T \text { and } \mu_{d} \simeq 1 / T\right) \\
\text { 高頻度-長継続 } \\
\left(\lambda_{d} \gg 1 / T \text { and } \mu_{d} \ll 1 / T\right)\end{array}$ & $\lambda_{s}$ \\
\hline
\end{tabular}

\section{4. 作動要求モードと $\omega^{*}$ の推定式}

$\lambda_{d}, \mu_{d}$ などの各パラメータ值が既知の場合, 式 (23) により $\omega^{*}$ を計算することができるが, 各パラメータ の大小関係, すなおち $T$ と $\lambda_{d}$ 及び $\mu_{d}$ の関係が明確 な場合には，より簡易的に $\omega^{*}$ を推定することができ る. この方法を表 1 に示す. この表では, $\omega^{*}$ の推定 式は 6 種類に分けられ 9 種類の作動要求モードが提案 されている.このうち,「低頻度-短継続」,「高頻度-短 継続」,「中頻度-長継続」,「高頻度-長継続」の各モード

ににおる推定式は加藤らによる定常状態作動要求の場 合の同様の各モードにおける推定式に一致する ${ }^{(6)}$. 任 意のリスク軽減目標に対して, 以下の方法により SIL を SRS に簡便に割り当てることができる.すなわち,

1. SRS を装備しない場合の全体システムの危険事象 頻度 (または, 危険事象発生率) を求める.（この 危険事象頻度は, 作動要求率 $\lambda_{d}$ と等価となる.)

2. 許容できるリスクのレベル及び本レベル内で収め るべき危険事象頻度 $\omega^{*}$ を決定する.

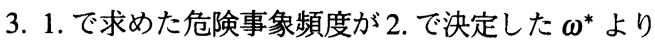
も高い場合, 表 1 から, 作動要求モードなどを勘 案しながら， $\omega^{*}$ を許容できるリスクの頻度以下 にする SRS の故障率 $\lambda_{s}$ を算出する.

4. 3. で算出した $\lambda_{s}$ を用いて SIL を決定し, 全体シ ステムに当該 SIL をもつ SRS を設置する.こう して, 全体システムの $\omega^{*}$ は, 許容リスクのそれ を下回ることになる.

\section{5.お り に}

IEC 61508 （JIS C 0508）を実施するには, SRS の作 動要求モードと危険事象頻度との関係を明らかにする 必要がある. そこで, 本報では, まずSRSに自己診断が ない全体システムを想定し, PT 時にEUCを停止する場 合, すなおち非定常作動要求状態における PT 間隔の危 険事象過程を順序依存形危険事象論理を用いてモデル 化した. 次に, これに基づき SRS の故障率, PT 間隔時 間, 作動要求率, 完了率及び PT 間隔平均危険事象頻度 $\omega^{*}$ との関係を定式化した. ここで導出された $\omega^{*}$ の推 定式は, 前提条件 (3) の $0<\lambda_{s} T \ll 1$ の条件下で導か れたものであるが, 規格の $\lambda_{s}$ の要件 $0<\lambda_{s}<10^{-5}[1 / h]$ 及び一般的な PT 間隔時間が約 $10^{4}[h]$ (約一年) 程度 であることを考慮すると，規格への適用は十分である と考えられる.さらに $\lambda_{d}, \mu_{d}$ 及び $T$ の関係を用いた 簡易的な $\omega^{*}$ の算出方法を示した.

本研究では順序依存形危険事象論理を用いてモデル 化を行なったが, この他の危険事象過程のモデル化と してマルコフ過程を用いるものが挙げられる. マルコ フ過程を用いて本報で得られた危険事象頻度推定式の 妥当性を検証することも興味深い研究課題となろう.

\section{文献}

(1) IEC 61508, (1998), IEC, Geneva.

(2) JIS C 0508, (1999), 日本規格協会.

(3) T.Kawahara, T.Kushibiki, K.Tsuboi, Y.Sato, SafetyIntegrity of Safety-Related System with Human Beings, Procs. the 5th International Conference on PSAM 2000, vol.4 (2000), 2411-2417.

(4) M.Yamashita, Y.Tanabe, K.Ohrui, Y.Sato, Safety Integrity of SRSs with Common Components, Procs. the 5th International Conference on PSAM 2000, vol.1 (2000), 473-479.

(5) 加藤栄一・佐藤吉信 ·堀籠教夫, 機能安全規格案におけ る安全度水準モデルについて, 信学論（A）, vol.J82-A no.2 (1999), 247-255.

(6) 加藤栄一 ·佐藤吉信 - 堀籠教夫, 機能安全規格案にお ける安全度水準モデルについて-前情におけるアルゴリ ズムの若干の修正, 信学技法, R99-18 (1999), 247-255.

(7) 佐藤吉信・井上紘一・熊本博光, 人間-ロボット系の安 全性評価（第 3 報, 順序依存形故障論理の定量化につ いて）, 機論, 52-475, C (1986), 1110-1117.

（8）龍偉・佐藤吉信, 共通の故障率と修復率をもつ順序依 存形故障論理の定量化（解析解の導出と FTA への適用 について）,機論，66-649, C (2000), 297-302.

（9）川原卓也·市塚昭弘・佐藤吉信，自己診断を有する安全 関連系の安全度水準モデル, REAJ 誌 2002, vol.24 No.8 (2002), 731-740.

（10）川原卓也·市塚昭弘・佐藤吉信, 自己診断を有する安全 関連系の状態遷移モデルと機能安全評価, 信学論 (A), vol.J86-A, no.3 (2003), 241-249. 
(11) JIS Z 8115, (2000), 日本規格協会.

(12) 関口隆·佐藤吉信, 機械安全機能安全実用マニュアル, 日刊工業新聞社, (2001).

(13) Mann, N.R., Method for Statistical Analysis of Reliability and Life Data, (1974), 121, John Willey \& Sons, New York.

(14) Henley, E.J. and Kumamoto, H., Probabilistic Risk Assessment and Management for Engineers and Scientists, 2nd ed., (1996), 303, IEEE Press. 